\title{
RELATIONS AND 16TH-CENTURY MEXICAN LOGIC
}

WALTER REDMOND

Huston-Tillotson College

Austin, Texas

0. It is a commonplace that before De Morgan, Frege, and Peirce there was no general logical theory of relations. ${ }^{1}$ Scholastic philosophers of course studied logical relations (syntactic and semantic, propositional and predicative, assertoric, modal, tensed, etc.) and had an ontological theory of relations. I suggest in this article that Alonso Gutiérrez de la Vera Cruz and others in the Scholastic tradition approached a theory of relations when they analyzed a type of categorical statement which was able formally to express relations. ${ }^{2}$

\section{Expansion of $L$}

1.1 To illustrate the Scholastic analyses, I will expand language $L$ previously presented in this Journal to include complex units. ${ }^{3}$ A unit (a subject or predicate) is simple if not made up

1 J. M. Bochenski, Formale Logik (Freiburg/Munich, 1956), p. 434; W. y M. Kneale, The Development of Logic (Oxford, 1962), pp. 510 ff. etc.

2 I cite the 1573 Salamanca edition of Alonso's Recognitio Summularum (indicating page number and column A or B) or the first (Mexican) edition of 1554 (indicating folio number, side $r$ or $v$, and column A or B). We refer mainly to chapters 15, 17, 18 and 20 (Salamanca edition): propositio cathegorica de extremis conditionatis/copulatis/disjunctis. Since I append the Latin original, my translations are rather free.

3 Crítica (Universidad Nacional Autónoma de México), “Extensional 
of other units. A complex unit is made up of (at least) two units joined by a junctor. A junctor may be of three types:

$c$ : forms a conjoined

$d:$ forms a disjoined

$i$ : forms a conditioned

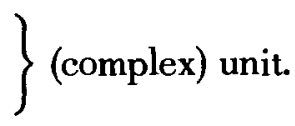

There are two kinds of complex units: divisive and complexive.

\subsection{Divisive units}

1.2.1 A divisive unit is a definition or abbreviation of a molecular sentence (a conjunction, disjunction, or implication):

$$
\Phi U J V=_{d f} \Phi U C \Phi V,
$$

where (in any order) $\Phi$ is a unit with or without a negation sign or modal operator, $U$ and $V$ are units, $J$ is a junctor, and $C$ is a propositional connective corresponding to $J$ in the following way. $C$ is:

$\&$ if and only if $J$ is $c$

$V$ if and only if $J$ is $d$

$>$ if and only if $J$ is $i$.

If $\Phi U C \Phi V$ is a sentence, then $\Phi U J V$ is a sentence.

1.2.2 The rule justifying inference of a definiendum from its definition or vice versa is called " $r p=$ ".

\subsubsection{Examples of divisive sentences:}

$s c p[h]$ (Socrates and Plato are human); abbreviation of: $s[h] \& p[h]$ (Socrates is human and Plato is human):

Interpretation of General Sentences in Sixteenth-Century Ibero American Logic," v. 13, n. 39 (Dec. 1981), pp. 45-73 and "Modal Logic in SixteenthCentury Mexico," v. 15, n. 43 (April, 1983), pp. 31-50, reprinted in Pensamiento y realidad en Fray Alonso de la Vera Cruz (W. Redmond and M. Beuchot, México, 1987). Divisive units are extensively treated in chapter 4 of this work, "La lógica de las unidades divididas", pp. 55-64. 


$$
\begin{array}{l|l}
1 & s c p[h] \\
2 & s[h] \& p[h]
\end{array} \quad 1 \mathrm{rp}=.
$$

$p[w] c[b]$ (Plato was white and black); abbreviation of: $p[w]$ $\& p[b]$ (Socrates was white and Socrates was black)

$[h] d x /(h)$ (a human being or Chimera is not human); abbreviation of : $[h] /(h) \vee x /(h)$ (a human being is not human or Chimera is not human).

\subsection{Complexive units}

1.3.1 If $U J V$ is a complex unit, then $|U J V|$, i.e., the unit enclosed by (vertical) bars, is a complexive (complex) unit, and $\Phi|U J V|$ is a sentence. The complex unit, or the sentence it forms part of, may be called, as the case may be, divisive or complexive, or conjoined, disjoined, or conditioned.

\subsubsection{We have, then, these types of units in general:}

simple:

proper name (or definite description); e.g., " $s$ ": Socrates

$$
\text { vague term; e.g., " } h_{1} \text { ": this (number } 1 \text { ) human being }
$$

universally quantified variable; e.g., “(w)": every white (entity)

particularly quantified variable; e. g., "[ $h]$ ": some human being

complex:

divisive units; e.g., "scp": Socrates and Plato complexive units; e.g. "|scp|": Socrates-and-Plato. ${ }^{4}$

1.3.2 Complexive units are twofold: single and multiple sense. ${ }^{5}$

4 I use hyphens to indicate complexive units in English.

5 This interpretation is provisional. The following text on conditional 
1.3.2.1 Single-sense units (whose inner terms are "taken together" in a single meaning or "as a whole") function as vague terms (when they are marked by a numerical index) or as variables (when quantified). Quantification of inner terms is avoided, and inner vague terms may appear without numerical index. Thus we have:

vague term: $|S J T|_{1}$ (where $S$ and $T$ are terms); e.g., " $\left.m c f\right|_{1}$ ": this (number 1) matter-and-form (combination) universally quantified variable: $(|S J T|)$; e.g., " $(|m c f|)$ ": every matter-and-form (combination)

particularly quantified variable: [|SJT|]; e.g., "[|mcf $\mid]$ ”: some (at least one) matter-and-form (combination)

1.3.2.2 Multiple-sense units (whose inner terms are "taken separately" in several meanings) do not function as vague terms nor are they quantified. However, they may contain vague or quantified terms. Thus we have: $|U J V|$; examples:

proper names: e.g., "|scp|": the pair Socrates-and-Plato combinations of proper names, vague terms, and quantified variables:

$$
\begin{aligned}
& \text { "|}|(h) c(a)| ": \text { every-human-being-and-every-angel } \\
& \text { " }|s c(a)| ": \text { Socrates-and-every-angel } \\
& \text { "|[h]cp|": some-human-and-Plato } \\
& \text { " }\left|h_{2} c a_{1}\right| ": \text { that-human-and-this-angel } \\
& \text { "|sch } \mid ": \text { Socrates-and-this-human }
\end{aligned}
$$

units appears (41rA) only in the first edition: "est notandum conditionatum capi unice et non unice: unice tunc est quando conditionatum captum a parte subjecti vel praedicati aliquo signo modificatur;... itaque tunc pluribus accipitur quando ponitur a parte praedicati absque aliquo signo cadenti super ipsum" ("the conditioned unit is taken either in a single sense or in several; it has a single sense when quantified and several when standing as an unquantified predicate"). 


\section{Conjoined complexive unit}

2.0 I examine first the multiple-sense (2.1), then the singlesense (2.2), conjoined complexive units.

\subsection{Multiple sense}

\subsubsection{Disputing}

\subsubsection{In the statement}

Socrates and Plato dispute,

translatable as $|s c p|[d]$, the unit " $|s c p|$ " is analyzed as any particular term in a categorical sentence:

1||$s c p \mid[d]$

$2 \nmid s c p\left|d_{1} \vee\right| s c p\left|d_{2} \vee \ldots \vee\right| s c p \mid d_{n}$

$1 \mathrm{DD}^{6}$

This analysis contrasts with that of the divisive sentence "scp $[h]$ ":

$$
\begin{array}{l|ll}
1 & s c p[h] & \\
2 & s[h] \& p[h] & 1 \mathrm{rp}= \\
3 & \left\{s h_{1} \vee s h_{2} \vee \ldots \vee s h_{n}\right\} \&\left\{p h_{1} \vee p h_{2} \vee \ldots \vee p h_{m}\right\} 2 \mathrm{DD}(2) .
\end{array}
$$

2.1.1.2 Let us compare the semantics of two sentences: one with simple units and the other with a complexive unit. Supposing $s h_{1}$ to be the true disjunct of the analysis of $s[h]$, we have this schema: ${ }^{7}$

6 "Et ad veritatem propositionis de copulato complexive tento oportet advertere ad suppositionem extremorum" ("to verify a conjoined complexive unit sentence, the reference of its units must be taken into account" 79A).

7 "Quomodo cognoscenda sit veritas propositionis de copulato extremo complexive sumpto, oportet eam cognoscere sicut veritatem aliarum cathegoricarum cognoscimus, scilicet: si copulatum sit terminus communis per ascensum aut sub toto si totum unica acceptione modificatur aut sub partibus si accipiantur pluribus acceptionibus, et cum supponit singulariter debet per suppositionem extremorum probari et in verificatione oporte maneat ly et 
universal property

concrete individual (Socrates)

proper name (of the individual) vague name (of the individual) sentence (disjunct of $s[h]$ )

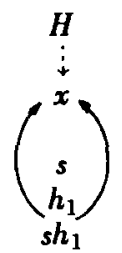

$\left.\begin{array}{l}\text { befitting } \\ \text { relation }\end{array}\right\}$ extralinguistic $\left.\begin{array}{l}\text { gemantics } \\ \text { relations }\end{array}\right\}$ linguistic

Socrates is named " $h_{1}$ " because the monadic property $H$ befits or applies to him; that is, he is called "this (number one) human being" because he is human. In the sentence the identity of $s$ and $h_{1}$ is stated.

2.1.1.3 If " $|s c p| d_{1}$ " is taken as the true disjunct of the analysis of " $|s c p|[d]$ ", we have this schema:

universal property

(the pair of) concrete individuals (Socrates-and-Plato)

proper name (of the pair)

vague name (of the pair)

sentence (disjunct of $|\operatorname{scp}|[d]$ )

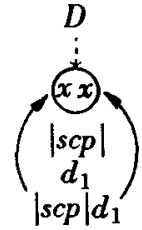

The unit $|s c p|$ refers to the (ordered) pair, and $D$ is a property of the pair. ${ }^{8}$ Alonso seems to take $D$ as "disputing at the same time" or "disputing together" (79A). ${ }^{9}$ Hence the pair $|s c p|$ is

cum non sit universalitas" ("the conjoint complexive sentence is verified as other categoricals: by an ascent if the unit is universal (under the unit as whole if it is single-sense and under its parts if multiple-sense), and by verifying the reference of the units if the unit is singular -in any case, since the sentence is not a conjunction, 'and' must remain a part of the analysis" $79 \mathrm{AB}$ ).

8 What we say of a pair presumibly applies, mutatis mutandis, to a triple, etc. A pair may be designated by a conjoined unit with vague terrns; e.g., $|s c p|$ is also named " $\left|h_{1} c h_{2}\right|$," i.e., "this-human-and-that-human" (Socrates and Plato).

9 E.g.: "totum copulatum dicitur supponere, si quaelibet pars ejus supponat et pro eodem instanti" ("the unit is said to have reference as a whole if each of its terms has reference and at the same time" 79A). 
called " $d_{1}$ " in virtue of the fact that $D$ applies to it; that is, the pair Socrates-and-Plato is called "this (number one) disputing pair" because they dispute at the same time. In the sentence the identity of $|s c p|$ and $d_{1}$ is stated.

2.1.1.4 The divisive sentence $s c p[h]$ expresses the relation of conjunction of the molecular sentence "Socrates is human and Plato is human" (80B). But the complexive sentence $|s c p|[d]$ is categorical (approximately, atomic) in which a property is predicated of a pair. In $L$ bars set off the complexive unit; Alonso and his contemporaries gave grammatical rules, natural and artificial, to recognize the divisive and complexive senses. ${ }^{10}$

2.1.1.5 The Latin phrase corresponding to $[d]$ seems to express a dyadic property or relation, and the sentence corresponding to $|s c p|[d]$ parallels modern notations such as $D s p$ or $s D p$. For Alonso simultaneity is an ingredient of $[d]$, but other examples he gave of complexive units have different contents (not involving tense logic). He remained within the framework of a double subject or predicate (but see 2.1.4.2).

\subsubsection{Binarity}

\subsubsection{Another of Alonso's examples (79B) is intriguing:}

10 E.g., "si copulatum ponatur a parte praedicati post verbum ruiuscunque numeri sit, aut quando ponitur a parte subjecti et terminatur unica acceptione ab aliquo signo, propositio non est distinguenda sed tale copulatum accipitur complexive; ... sed quando copulatum ponitur a parte praedicati ante verbum, aut est subjectum cujus omnes partes sunt pluralis numeri et verbum est pluralis numeri, tunc propusitio est distinguenda, quia copulatum potest sumi divisive et complexive" ("a conjoined unit is complexive, and need not be distinguished, when it stands as a predicate and follows a singular or plural verb, or when it stands as the subject and a cuantifier limits it to single sense; ... but when it is a predicate preceeding the verb, or when it is a subject whose terms and the verb are plural, then the sentence should be distinguished, since the unit may be taken either divisively or complexively" 79A). 
every human being and every angel is binary,

which may mean that people and angels bear some one-on-one relation, perhaps $(x)(y)[[H x \& A y]>B x y]$, and I hazard the interpretation $|(h) c(a)|[b] .{ }^{11}$ To carry out the analysis we need rules allowing ascent and descent within the complexive unit:

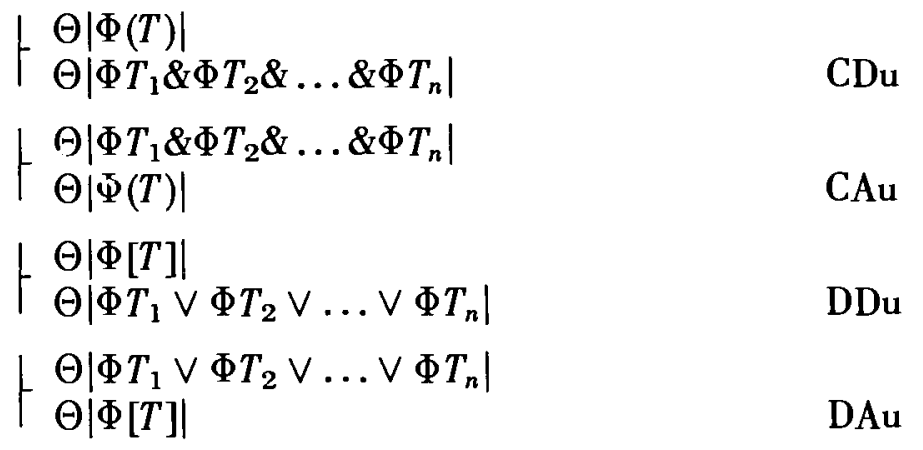

where $\Theta$ is a unit with or without a negative or modal operator, $\Phi$ is a complexive unit containing the term $T$. We also need rules to distribute the bars:

$$
\begin{aligned}
& \text { ᄂ } \Theta\left|\Phi T_{1} C \Phi T_{2} C \ldots C \Phi T_{n}\right| \\
& \Theta\left|\Phi T_{1}\right| C \Theta\left|\Phi T_{2}\right| C \ldots C \Theta\left|\Phi T_{n}\right| \\
& \text { - } \Theta\left|\Phi T_{1}\right| C \Theta\left|\Phi T_{2}\right| C \ldots C \Theta\left|\Phi T_{n}\right| \\
& \Theta\left|\Phi T_{1} C \Phi T_{2} C \ldots C \Phi T_{n}\right|
\end{aligned}
$$

where $C$ is a propositional connective.

11 After the passage given in note 7, Alonso gives omnis homo et omnis angelus est binarius as an example, and continues, with some ambiguity: "veritas hujus... toto distributo cognoscitur per ascensum sub toto, et si solum prima pars distribuatur, ascensus fiat solum sub prima parte ac deinde sub secunda" (this sentence, "since the whole unit is universally quantified, is verified by an ascent on the whole unit; but if only the first term is thus quantified, the ascent is carried out on the first term only and afterwards on the second.") A general form like $(x)(y) B x y$ would correspond to $|(e) c(e)|[b]$, where " $e$ ": entity, defined as we wish. 
2.1.2.2 The descent would be, in a universe of two people and two angels:

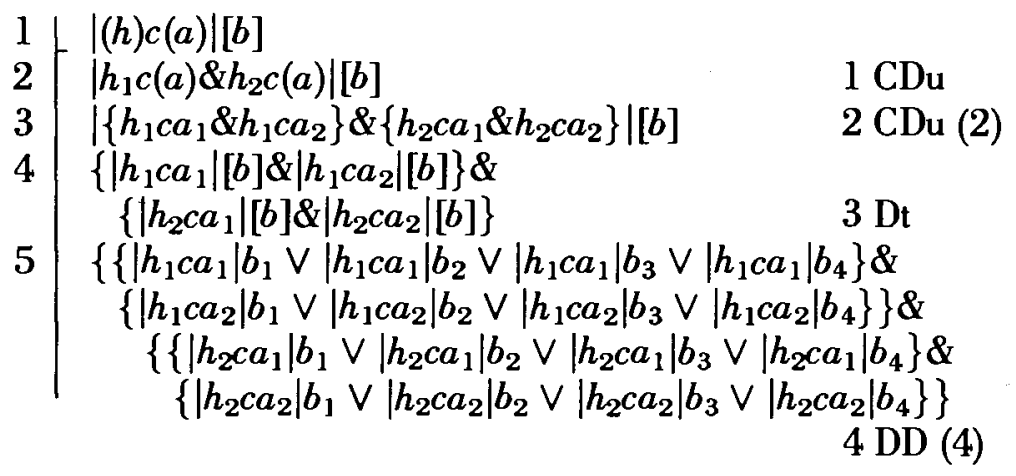

We have here, if this interpretation is correct, the quantification of the terms of a relation. If $\left|h_{1} c a_{1}\right| b_{1}$ is a true disjunct, the pair this-human-and-this-angel is called " $\left|h_{1} c a_{1}\right|$ " because the properties $H$ and $A$ apply respectively to the members of the pair, and because they stand to one another in the relation $B$; moreover, they are called " $b_{1}$ " in virtue of being terms of "this" relation. In the sentence the identity of $\left|h_{1} c a_{1}\right|$ and $b_{1}$ is affirmed.

\subsubsection{Numbers}

Alonso offers a sort of number theory in this context. The divisive version of "heaven and earth are a single thing" (yielding $h[o] \& e[o])$ he says $(80 \mathrm{AB})$ is true, and false (81A) the divisive version of "Plato and Socrates are two" (yielding $p[t] \& s[t]$ ). The expression of one (with reference to Plato) would be the simple categorical $p[o]$, and of $t w o$ (with reference to Socrates and Plato) the complexive form $|s c p|[t]$; the respective analyses would be, say, $p o_{2}$ and $|p c s| t_{3}$. That is, Plato is called " $o_{2}$ " because the property $O$, that of being a single entity, applies to him, and Plato-and-Socrates is called " $t_{3}$ " because the property of being two entities belongs to the pair. Hence in general 
numbers function as properties: monadic in the case one, and polyadic in the case of numbers greater than one.

\subsubsection{More complicated language}

2.1.4.1 The scholastics worked within a subject-verb-object sentence schema in the case of the traditional logical conundrum of the two people carrying a rock together which each cannot carry alone. The divisive version, $s c p[k]$, where $k$ means carryiing the rock, is therefore false. The multiple-sense complexive version, $|s c p|[k]$ would give this analysis: ${ }^{12}$

1||$s c p \mid[k]$

$2\left\lceil|s c p| k_{1} \vee|s c p| k_{2} \vee \ldots \vee|s c p| k_{n}\right.$

which appears to be correct.

2.1.4.2 However, Alonso considers (80A) the objection that the following multiple-sense interpretation would imply that each person carries the rock alone:

Socrates-and-Plato carry-a-rock-and-carry-a-rock. ${ }^{13}$

Alonso plunks for this "analysis of the conjoined unit taken in a single sense":

Socrates-and-Plato carry-and-carry a rock. ${ }^{14}$

The single-sense ( $c f .2 .2)$ phrase "carry-and-carry" conveys the relation of a pair carrying something together. So Socratesand-Plato are called " $k_{1}$ " since the relation of carrying-andcarrying a rock at the same time belongs to them. This exam-

12 Petrus et Paulus portant lapidem (we use Socrates and Plato). Another similar puzzle (80A): two people know all the liberal arts, since one knows three and the other four.

13 "Petrus et Paulus sunt portans lapidem et portans lapidem."

14 "Resolutio debet fieri incopulatum unica acceptione captum:... sunt portans et portans lapidem." 
ple, representable as $|s c p|[l][r]$, where " $l$ " (or the single-sense "|kck|"): carry together and " $r$ ": rock, shows the internal complexity of the categorical sentence for Alonso. ${ }^{15}$

\subsection{Single sense}

\subsubsection{White and black}

2.2.1.1 The sentence "Plato was white and black" contains a complexive unit joining two predicates. Note the analysis of the divisive version $p[w] c[b]$ :

$$
\begin{array}{l|l}
1 & p[w] c[b] \\
2 & p[w] \& p[b] \\
3 & \left\{p w_{1} \vee p w_{2} \vee \ldots \vee \vee w_{n}\right\} \&\left\{p b_{1} \vee p b_{2} \vee \ldots \vee p b_{m}\right\}
\end{array}
$$

Alonso thinks (79A) the sentence is true in case Plato "was white yesterday and black the day before". But the complexive version is false, he says, since it implies that he was white and black at the same time. ${ }^{16}$

2.2.1.2 The single-sense version would be $p[|w c b|]$. We have this descent in a universe of two beings:

\begin{tabular}{l|l}
1 & $p[|w c b|]$ \\
2 & $p|w c b|_{1} \vee p|w c b|_{2} \vee p|w c b|_{3} \vee p|w c b|_{4}$
\end{tabular}

15 For multiple quantification in Alonso see "Extensional Interpretation of General Sentences in Sixteenth-Century Ibero-American Logic", Crítica (Universidad Nacional Autónoma de México), vol. xiii, n. 39, dec., 1981, 45-73, and "Un ejemplo de la cuantificación múltiple en la lógica del siglo xvi", Revista de filosofía (Universidad Iberoamericana, México), año xiv, n. $40,1980,27-37$. The analysis of $|s c p|[l][r]$ would be: $\left\{|s c p| l_{1} r_{1} \vee|s c p| l_{2} r_{2} \vee\right.$ $\ldots\} \vee\left\{|s c p| \psi_{2} r_{1} \vee \ldots\right\} \vee \ldots$.

16 "Nam totum copulatum simul non supponit pro Petro licet quaelibet pars ejus supponat pro eo" ("even though both terms of the unit refer to Peter, the unit as a whole does not refer to Peter at the same time"). 
The semantics would be as follows (let us take $p|w c b|_{4}$ as one of the false disjuncts):

(pair of) universal properties

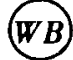

concrete individual (Plato)

proper name (of the individual)

(false) vague name (of the individual)

(false) sentence

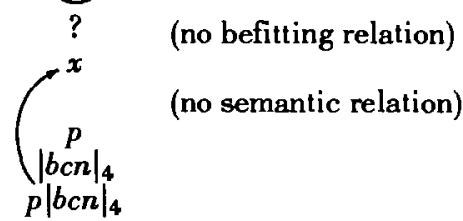

The unit $|w c b|_{4}$ does not refer to Plato, nor is he called " $|w c b|_{4}$ ", since he does not examplify the properties $W$ and $B$ related in this way. The double predicate is not the mere intersection of $W$ and $B$ (this would be the divisive version), but includes the notion of past simultaneity. ${ }^{17}$

\subsubsection{Philosophy}

2.2.2.1 Alonso analyses the logical structure of complex sentences about the ontological make-up of the individual. He claims (79A) that the complexive (single-sense) interpretation of "a man is matter and form" is true:

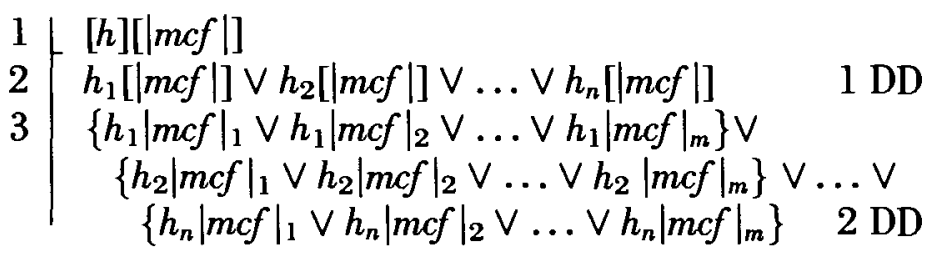

17 A multiple-sense analysis would be:

\begin{tabular}{l|ll}
1 & $p|[w] c[b]|$ & \\
2 & $p\left|w_{1} c[b] \vee w_{2} c[b]\right|$ & $1 \mathrm{DDu}$ \\
3 & $p\left|\left\{w_{1} c b_{1} \vee w_{1} c b_{2}\right\} \vee\left\{w_{2} c b_{1} \vee w_{2} c b_{2}\right\}\right|$ & $2 \mathrm{DDu}(2)$ \\
4 & $\left\{p\left|w_{1} c b_{1}\right| \vee p\left|w_{1} c b_{2}\right|\right\} \vee\left\{p\left|w_{2} c b_{1}\right| \vee p\left|w_{2} c b_{2}\right|\right\}$ & $3 \mathrm{Dt}$
\end{tabular} 
2.2.2.2 Taking $h_{1}|m c f|_{1}$ as a true disjunct, the human being $\left(h_{1}\right.$, Socrates) is called " $|m c f|_{1}$ ", i.e, "this matter-and-form", because in Alonso's ontology, Socrates' concrete being is a unity of a certain portion of matter specified by a certain form. ${ }^{18}$ The friar denies (79B) that the complexive version implies the divisive one, since in the following argument the antecedent is true and the consequent false:

\begin{tabular}{l|l}
1 & {$[h][|m c f|]$} \\
2 & {$[h][m] c[f]$}
\end{tabular}

incorrect

All disjuncts of the analysis of $[h][m] c[f]\left(\text { e.g., } h_{1} m_{1} \& h_{1} f_{1}\right)^{19}$ are false, since Plato is not ontologically identical either with his matter alone or with his form alone.

\subsection{Conclusion}

As these examples show, Alonso (79AB) and his contemporaries worked with patterns of categorical sentences more complex than simple subject plus predicate. They had at their disposal analytical techniques allowing them to treat relations and their quantification. ${ }^{20}$

\section{The disjoined complexive unit}

3.1 The Scholastics were interested in sentences having conditioned and disjoined units (i.e., where the junctors are $i$ and $d$ ), since they occur in natural language. Now, although the sense of disjoined and conditioned divisive sentences is obvious, it is

18 Cf. the Thomist individuation theory of materia signata quantitate and the substantial form related as potency and act.

19 I observe the MS restriction (see L58) and apply first $D D\left(h_{1}[m] c[f] \mathrm{V}\right.$ $h_{2}[m] c[f] \vee \ldots$ ) and then $r f=$. Alonso also denies (79B) that $p[m c]$ implies the disjoined divisive $p[m] d[f]$ or its disjunction $p[m] \vee p[f]$, since both disjuncts are false.

20 Note how these analyses apply to quantification exercises: "Women and children enter the lifeboats first" is $(x)[[W x \vee C x]>F x]$; in $L$ the "and" is retained in the correct divisive interpretation $(w) c(c)[f]$. 
harder to understand the complexive sense. Basically, the terms of a complexive unit are related by different truth functions: if conjoined, the unit counts only if both terms count, if disjoined, the unit counts as long as one term counts, and if conditioned, the unit counts as long as the antecedent does not count without the consequent counting.

3.2 Alonso spent most of his time on conjoined units and made short shrift (77AB) of the conditioned ones, and his teacher D. Soto even doubted whether "si" in Latin ever has the conditioned sense. ${ }^{21}$ Alonso also reduced the complexive to the divisive disjoined unit except in specific cases. ${ }^{22}$

3.3 One such case is the negative sentence "some human being or Chimera is not human." It is false in the complexive sense, he says, because given its truth function, the disjoined unit has reference even if one of its terms does not. ${ }^{23}$ If my interpretation is correct, we have the analysis ( $c f$. the procedure in 2.1.2.2):

$$
\begin{array}{l|ll}
1 & |[h] d x| /(h) & \\
2 & \left|h_{1} d x \vee h_{2} d x \vee \ldots \vee h_{n} d x\right| /(h) & \\
3 & \left|h_{1} d x\right| /(h) \vee\left|h_{2} d x\right| /(h) \vee \ldots \vee\left|h_{n} d x\right| /(h) & 2 \mathrm{DDu},
\end{array}
$$

and if $x$ is cancelled out:

$$
h_{1} /(h) \vee h_{2} /(h) \vee \ldots \vee h_{n} /(h),
$$

21 Summularum editio postrema, 1575, 62vB.

22 "Quando disjunctum non singularizatur neque distribuitur, aequivalet disjunctum complexive et divisive tentum; ut homo vel equus currit; perinde est quod divisive vel complexive sumatur, sed in negativis non sic, ut in exemplo supra posito/ homo vel Chymera non est homo" ("as long as it is not singular nor universally quantified, the disjoined complexive unit is equivalent to the divisive; thus e.g. 'a human being or a horse runs' may be taken as divisive or complexive; this, however, is not so with negative sentences, such as 'as human being or Chimera is not human" " $82 \mathrm{~B}),[h] /(h)$ by DA.

23 "Quia in disjunctis complexive tentis, si una pars supponit et alia non, pars non supponens convertitur cum supponente" ("for if one term has reference and the other does not, the first is converted with the second" 82B). 
where each conjunct must be false. ${ }^{24}$

3.4 On the other hand, he says (82B), the divisive version is true:

$1 /[h] d x /(h)$

$2\left[\frac{[h] /(h) \vee x /(h)}{2(h) /(h) \vee h(t h) ~}\right.$

$3\left\{\left\{h_{1} /(h) \vee h_{2} /(h) \vee \ldots \vee h_{n} /(h)\right\} \vee x /(h) \quad 2\right.$ DD.

The last disjunct is true ("Chimera is not human") while all the others are false.

\section{Reflection}

4.1 At the end of this section, Alonso says $(83 \mathrm{~B} / 44 \mathrm{vB})$ he is skipping the "useless" analyses of other logicians, and in the Salamanca edition he thinks he should cut even more "for the sake of beginners, who like to wage war even if only beating the air". ${ }^{25}$ He eliminated from the Salamanca edition two complex puzzles on conjoined complexive units he had included in the first edition (42vA43rA) "to avoid the impression of scorning our old teachers, whose judgment is not distorted."26

4.2 The point of the second puzzle, by Pedro Espinosa, is to identify the correct logical relationship between two sentences with complex quantification about members of a pair:

24 "Et ob id aequivalet illa huic: homo non est homo" ("hence it is equivalent to the sentence: 'a human being is not human'" $82 \mathrm{~B}$ ).

25 "...et tamen circa omnia quae in primo tractatu Summularum adduci solent ex proposito relinquimus quae non conducunt, necessaria vero sic sunt apposita ut nil utile sit desiderandum". Salamanca addition: "imo adhuc nonnulla merito resecanda sunt inutiliter satis apposita propter tyrones quibus belligerare, etiamsi aerem verberent, gratum est".

26 "... ne videamur contemnere nostros alias magistros... qui depravatum non habent judicium, esse oleum perdere in his versari." 
"the other", "both", etc. ${ }^{27}$ Alonso covered it in the Mexican edition to show how useless these exercise can be.

Unless I am mistaken, they are worth only to be trodden underfoot. Not only are they vain and stupid, but they make people who waste their time on them vain and stupid. After exhausting themselves with endless toil, their hands are empty.

Can we really pretend it is not wasted energy to go on about "the two" and "the other" and syllogisms with "d" and "c" quantification? Spending time on important matters is better than teaching riddles even their inventors hardly understand. I do not regret saying this, for to unravel the cloth they weave, with all their observations and distinctions, they sometimes create monsters worse than the first; as soon as they lop off one of the Hydra's heads, other sprout forth.

On the other hand, as we leave such things behind, let us avoid carelessness and indolence in teaching what is solid and important; the students should not be cheated by one jot or tittle. Now the Saturnian kingdoms are coming back, a new golden age has begun! ${ }^{28}$

27 "Utrunque animal .a. altera medietas hominis et quaelibet medietas hominis non est / alterum animal utraque medietas hominis et medietas hominis est" (42vB).

28 "Haec Spinosa quae a nobis exempli causa adducta volo, ex quibus colligere licet quam sine fructu ista ab eis sint tradita, profecto ni [correcting "in"] fallor ad nihilum valent ultra nisi ut conculcentur ab hominibus. Quia non solum vana et fatua sunt sed vanos et fatuos reddunt homines qui in ipsis perdiscendis tempus consumunt, et post innumeros exhantlatos labores nil inveniunt in manibus suis. Nonne oleum et operam perdere est in hujusmodi de uterque et de alter et de mixtis de ly $d$ et ly = syllogismis insistere et solum ad libitum fingere prorsus invanum? Prasstaret enim in re seria bonas collocare horas et operae pretium agere quam sic traducere iuventutem istis quae vix intelliguntur ab ipsis qui illa ad libitum fingunt. Dixi vix intelligunt neque paenitet dixisse, quia aliquando ut tellam succidant quam orsi sunt pro notabilibus et distinctionibus, alia monstra prioribus pejora fingunt. Ut sic uno Lerneae [correcting "leernae"] capite amputato alia plura renascantur, ex animo valefaciamus. Et longe a tergo relinquentes, istorum prudenter obliti quae nervosa quae momenti sunt non socorditer et somniculose tradenda erunt neque in jota aut apice discipulos defraudantes. Redeunt jam Saturnia regna, jam aureum saeculum pulullare incipit." 
4.3 Alonso alludes to a university reform he mentions in the forward of his work (4rB). About the middle of the 16th century teachers in Iberia and her colonies simplified their textbooks and criticized the complicated analyses of logicians who had published their works in the first third of the century. Nevertheless, pace Vives and company, what inveterate logician -as Alonso himself in his youth - would not be tempted to "wage war" on quantification theory and the logic of relations?

4.4 The following schema show some parallels between Alonso's classification of sentences and one we might find today. Technical words are italicized. The singular sentence $s h_{1}$ (also used to exemplify the present-day identity sentence), is an element of the analysis of a general sentence (other examples are possible). In this Scholastic interpretation, any general sentence must be quantified because it lacks complete analysis. The universal sentence may suppose existential import in Scholastic logic. The existential and universal quantification examples: "some/every human is mortal." Disjoined and conditioned complexive sentences are omitted (3.2). For my example $|(e) c(e)|[b]$ see note 11 . Scholastic logicians discussed whether the divisive sentence is categorical or hypothetical. My example of the conditioned divisive is expanded thus: "If Socrates is human, then Socrates is mortal." Alonso, as we today, used truth-functional definitions of conjunction and disjunction, but added modality (necessity) to that of conditionals, like our strict implication (he added a purely truth-functional interpretation). 
The sentence:

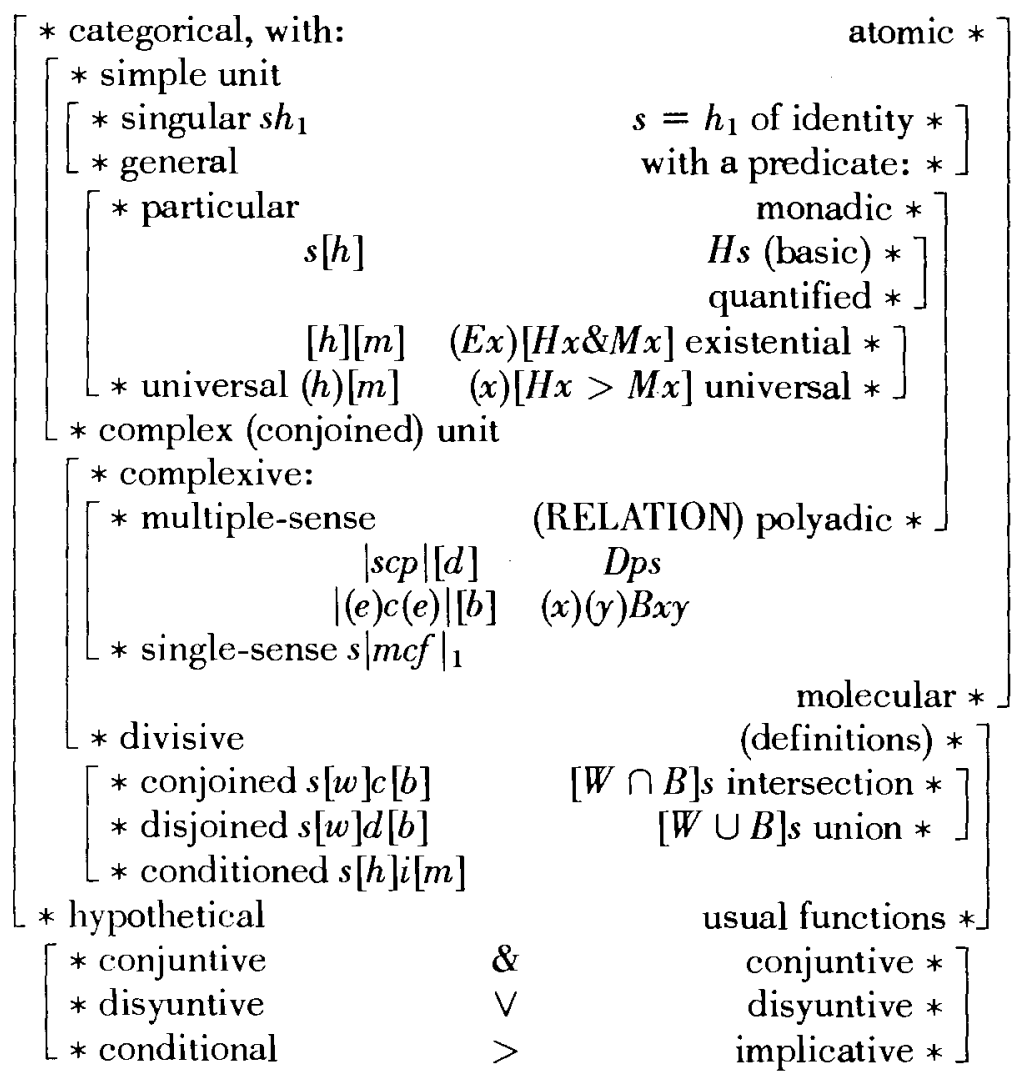

Recibido: 13 diciembne 1989. 


\section{RESUMEN}

Fray Alonso de la Vera Cruz y sus colegas del siglo XVI analizaban las relaciones lógicas, sintácticas y semánticas, y tenían una teoría ontológica de las relaciones, pero no trabajaban con una teoría general lógica de las relaciones. Sin embargo su investigación de algunos temas, como el de la oración de dobles sujetos/predicados “conjuntadas complexivamente de acepción múltiple" rayaba en una concepción general de la relación.

Ejemplo de tal oración es "Sócrates y Platón disputan", formalizable en el lenguaje L como " $|s c p|[d]$ ". " $|s c p| "$ representa el sujeto doble y funciona como un nombre propio. El predicado " $[d]$ " está cuantificado particularemente, como es normal en este tipo de oración. Recibe un análisis normal:

$\begin{aligned} & 1 \\ & 2\end{aligned} \mid \begin{aligned} & |s c p|[d] \\ & |s c p| d_{1} \vee|s c p| d_{2} \vee \ldots \vee \\ & \end{aligned}$

La semántica es como la de la oración de sujeto/predicado sencillo. Si " $s h_{1}$ " es el disyunto verdadero del análisis de "s[h]", "Sócrates es un ser humano", se afirma en él la identidad de "Sócrates" y "este ser humano", es decir, que " $s$ " y " $h$ ", se refieren a la misma cosa. Así mismo, el disyunto verdadero de " $|s c p|[d]$ ", digamos " $|s c p| d_{2}$ " afirma que " $|s c p| " \mathrm{y}$ " $d_{2}$ " se refieren a la misma cosa, pero en este caso al par de Sócrates y Platón.

Otros ejemplos de Alonso, como "todo ser humano y todo ángel es binario" muestran cómo pueden cuantificarse independientemente los términos del sujeto complejo.

Alonso no llegó a la relación pura no tanto porque suponía a menudo un elemento de temporalidad ("disputan a la vez"), sino porque pareció quedarse dentro del marco de los dobles sujetos y predicados. Sin embargo, cuantificó el objeto de una oración con doble sujeto: "Sócrates y Platón llevan-y-llevan una piedra" (|scp|[l][p]").

En la p. 40 se muestran unas correspondencias aproximadas entre el enfoque escolático de la oración y uno que podríamos encontrar hoy.

[W. R.] 